\title{
Browser impacts in Mapungubwe National Park, South Africa: Should we be worried?
}

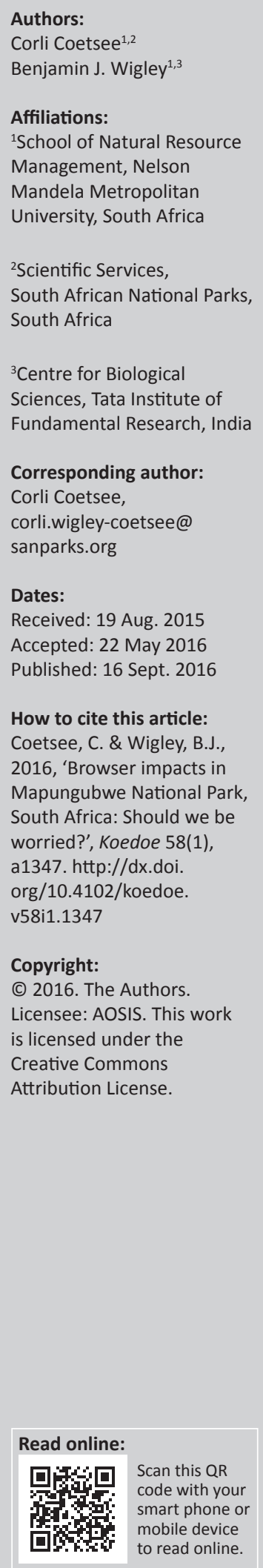

This study explores the impact of browsers on vegetation types within the Mapungubwe National Park and specifically whether rocky outcrops or ridges in the park serve as refugia from browsers, particularly elephants. We sampled 80 transects at 20 sites and recorded 1740 plants comprising 65 species. We found that a high proportion $(>80 \%)$ of the woody vegetation sampled indicated browser utilisation. Although certain woody species (e.g. Albizia harveyi, Boscia albitrunca, Lannea schweinfurthii) appeared to be preferred by browsers, browsing levels were relatively high among all woody species. High levels of browsing by herbivores other than elephants suggest that they have a significant impact on the park's vegetation. We did not find that rocky ridges acted as refugia to browsers, but instead found that vegetation in rocky ridges was more severely impacted by browsers than vegetation in flat areas, despite vegetation being more accessible in flat areas. If elephant numbers continue to increase at the current rate (e.g. elephant numbers doubled between 2007 and 2010), we predict that some of the heavily utilised species will become locally rare over time.

Conservation implications: High levels of browsing by both elephant and smaller herbivores contribute to significant impacts on vegetation away from rivers in Mapungubwe National Park. Without management interventions that address both types of impact, structural and species diversity are bound to decrease over the short to medium term.

\section{Introduction}

Elephants can have major, positive ecological effects on savanna dynamics (Campos-Arceiz \& Blake 2011; Kerley \& Landman 2006; Owen-Smith 1989), but they may also cause loss or extinction of woody and succulent plant species, especially in fenced conservation areas (De Beer et al. 2006; Gandiwa et al. 2011; Guldemond \& Van Aarde 2008; Kerley et al. 2008; Landman et al. 2014; O'Connor, Goodman \& Clegg 2007; Shannon et al. 2008).

Mapungubwe National Park (Mapungubwe), situated in the Shashe-Limpopo area of southern Africa, encompasses a World Heritage archaeological site which shows complex human societies existed there between AD 1100 and 1300 (Huffman 2000). Dating back to the 9th century, elephants were scarce in the Mapungubwe area, with the abundance of ivory found there being attributable to imports from Sofala (in present-day Mozambique, Huffman 2000). Prior to proclamation in 2004, Mapungubwe was state owned with little wildlife, elephants being mostly absent until the early 2000s (De Beer 2007; Selier 2007). Elephants, however, did occur in large numbers in the surrounding lands, including the Tuli Block area, Botswana (1.22 elephant $\mathrm{km}^{-2}$ in Tuli, Selier 2007).

The 'elephant problem', as conceptualised by Caughley (1976), suggested that elephants and vegetation have a stable, limit relationship, with the original number of elephant increasing as vegetation decreases, the situation being reversed when the drop in vegetation reaches a level beyond which it is unable to support an elephant population. O'Connor (2010) showed that elephants had limited impact on vegetation in Mapungubwe during the 1990s, but by 2005 their impact was more noticeable. The same study found that from 2005 to 2007, ring-barking of trees by elephants led to 3\% mortality in the riparian forest lining the Limpopo River. The riverine forest is an important foraging area for elephants in the dry season ( $\mathrm{O}^{\prime} \mathrm{Connor} 2010$ ) and ongoing monitoring has shown further mortality for some preferred riparian species (e.g. Faidherbia albida [ana tree] and Vachellia [Acacia] xanthophloea [fever tree]) (SAEON, unpublished data; OTS, unpublished data).

O'Connor and Page (2014) showed that in the Venetia Limpopo Nature Reserve, a neighbouring reserve to Mapungubwe, elephant impacts have spread from riverine areas to certain non-riparian dryland vegetation types. Similarly in Mapungubwe, thickets of Commiphora spp. (corkwood) outside riparian areas are being destroyed by elephants (C. Coetsee, pers. obs.). Assessment of 
elephant impacts on vegetation are further complicated when the effects of fire and other herbivores are included (Holdo 2007; Holdo, Holt \& Fryxell 2009; Moncrieff, Kruger \& Middgley 2008; Midgley, Lawes \& Chamaillé-Jammes 2010; Shannon et al. 2011; Valeix et al. 2011). While fire is not an important ecological driver in arid areas, herbivores are important agents of top-down control in savanna systems (Bond 2005). Browsing and mixed-feeding herbivore species (Table 1) may, either individually or in combination, significantly affect the woody vegetation dynamics in Mapungubwe.

This study assesses the impact of elephants and other herbivores on the woody component of the main vegetation types of Mapungubwe. Besides the measured levels of impact serving as a useful benchmark for future studies, we also wanted to evaluate the effect of specific localities, vegetation types and species on woody vegetation. The hypotheses that we tested were: (1) the impact of elephants and other browsers will be more severe for certain plant species within each vegetation type, (2) mesoherbivores contribute to the high levels of browser impact on the vegetation, (3) the impact of elephants and other browsers will be higher in certain vegetation types, with mopane-dominated vegetation being either more preferred because it is easily accessible on flat plains or less preferred because it grows in association with sandy and nutrient-poor soils and (4) vegetation on ridges will be less impacted as ridges will act as refugia from elephants. We could not measure whether elephants and other browsers prefer certain vegetation types or species as we did not measure rates (e.g. searching time, feeding time) of utilisation, instead we used direct impact as a proxy for preference. We made the assumption that the preference for a vegetation type was reflected by greater impact levels on it.

\section{Study site}

Mapungubwe National Park $\left(\sim 280 \mathrm{~km}^{2}\right)$ is situated on the southern banks of the Limpopo River in South Africa with Botswana and Zimbabwe on its northern border (Figure 1). Mapungubwe forms part of the Greater Mapungubwe Transfrontier Conservation Area (GMTFCA), an area of $3065 \mathrm{~km}^{2}$ which creates a continuous conservation area connecting South Africa, Botswana and Zimbabwe. The region is semi-arid with low and unpredictable rainfall of approximately $350 \mathrm{~mm}-400 \mathrm{~mm}$ per annum (O'Connor \& Kiker 2004). The mean annual temperature is $21.6^{\circ} \mathrm{C}$ with monthly minimum averages of $7.2^{\circ} \mathrm{C}-20.3^{\circ} \mathrm{C}$ and maximum averages of $24.7{ }^{\circ} \mathrm{C}-32{ }^{\circ} \mathrm{C}$ (Mucina \& Rutherford 2006; O'Connor \& Page 2014).

Mucina and Rutherford (2006) classified three main vegetation types in Mapungubwe: Subtropical Alluvial Vegetation, Musina Mopane Bushveld and Limpopo Ridge Bushveld, while riparian areas on the Limpopo River are classified as Lowveld Riverine Forest. These broad vegetation types were previously classified as seven separate vegetation types (see Table 2; maps in Scientific Services data repository, based on South African Defence Force 1986a, 1986b).
The area's geology comprises Archaean Beit Bridge Complex, younger basalts of the Karoo Supergroup and sandstones of the Clarens Formation (Mucina \& Rutherford 2006). Recent alluvial deposits with deep, fine-structured sandy to loamy soils are found along the rivers. The Limpopo River forms the northern boundary of Mapungubwe and several artificial watering points in the park provide water throughout the year. All our sampling sites were within $5 \mathrm{~km}$ of perennial water supplies and the average distance to water was $2.6 \mathrm{~km}$ (Scientific Services, unpublished data).

Between 2000 and 2010, the estimated mean density of elephants in the GMTFCA was 0.61 elephant per $\mathrm{km}^{-2}$, and

TABLE 1: Total numbers of browser and mixed feeder herbivore species in Mapungubwe National Park.

\begin{tabular}{lcc}
\hline Species & $\mathbf{2 0 0 7}$ & $\mathbf{2 0 1 0}$ \\
\hline Eland & 286 & 326 \\
Elephant & 213 & 404 \\
Gemsbok & 120 & 125 \\
Giraffe & 36 & 61 \\
Impala & 872 & 1490 \\
Kudu & 110 & 114 \\
\hline
\end{tabular}

Source: SANParks census data, Scientific Services data repository

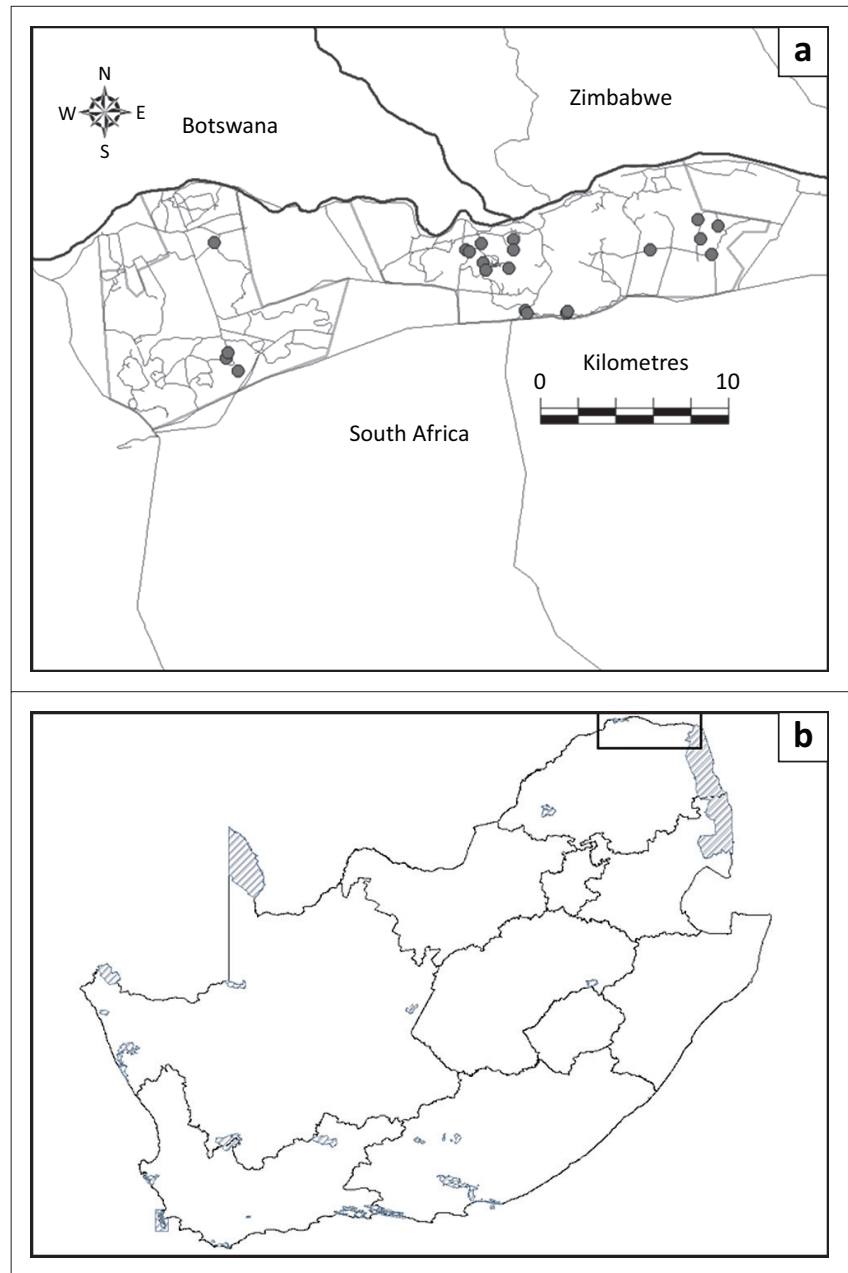

Source: Maps produced by B.J.W. from spatial layers provided by Scientific Services data repository

FIGURE 1: Map of the study sites: (a) study area with vegetation transect sites in the Mapungubwe National Park and (b) the position of the Mapungubwe National Park (blocked) within South Africa. 
biennial censuses indicated that the population varied between 1080 and 1294 elephants (mean of $1224 \pm 72$ s.d.) (Selier 2007). Census data from 2007 to 2010 indicate that eland, elephant, giraffe and impala numbers increased in Mapungubwe during this period (Table 1). Smaller species such as rock hyrax and klipspringer may be present in significant numbers but were excluded as they could not be counted. No census data predating 2007 are available for Mapungubwe.

\section{Methods \\ Data collection}

In January and October 2012, we sampled 80 transects, each $100 \mathrm{~m}$ long by $4 \mathrm{~m}$ wide, covering a total area of 3.2 ha. For each tree and shrub taller than $0.5 \mathrm{~m}$ within a transect, we noted its species, height and width of the canopy and browser impact classified as: (1) the percentage of branches browsed in four different categories $(0 \mathrm{~mm}-10 \mathrm{~mm}, 10 \mathrm{~mm}$ - $20 \mathrm{~mm}, 20 \mathrm{~mm}-50 \mathrm{~mm},>50 \mathrm{~mm}$ diameters) and (2) branches broken ( $>10 \mathrm{~mm}$ ), twigs browsed (diameter $<5 \mathrm{~mm}$ ), bark peeled, branches stripped (the end of branches higher than $2 \mathrm{~m}$ stripped of leaves in a manner typical of giraffe), trees toppled (pushed over) and pollarded (snapping of the main stem). This method is adapted from previous elephant impact surveys, including Shannon et al. (2008). Except for toppling, only damage that was estimated to have occurred during the past year or two (i.e. scars were still fresh) was recorded. Despite measurements being taken by the same observer to avoid observer bias, actual damage may have been consistently underestimated or overestimated. Browsing measurements were taken to canopy heights of $2 \mathrm{~m}$ and $5 \mathrm{~m}$ for small herbivores to mesoherbivores (twig scars and branches $<10 \mathrm{~mm}$ diameter).

Transects were placed in six vegetation types (Table 2) excluding riparian forest (Faidherbia albida-Panicum maximum Closed Woodland) which was assessed by previous impact studies. The Vachellia (Acacia) stuhlmannii Open Shrubland vegetation type was underrepresented because it occurs on old farmlands currently dominated by two unpalatable species with negligible browsing impact.

TABLE 2: The seven vegetation types found in Mapungubwe, total area and percentage of area covered by each type and number of transects sampled in each vegetation type.

\begin{tabular}{lccc}
\hline Vegetation Type & Area (Ha) & Area (\%) & Sites \\
\hline $\begin{array}{l}\text { Senegalia (Acacia) senegal-Barleria } \\
\text { sinensis Closed Shrubland }\end{array}$ & 4557 & 16 & 6 \\
$\begin{array}{l}\text { Colophospermum mopane - Brachiaria } \\
\text { deflexa Closed Woodland }\end{array}$ & 6066 & 21 & 4 \\
$\begin{array}{l}\text { Commiphora species - Sesamothamnus } \\
\text { lugardii Closed Shrubland }\end{array}$ & 2108 & 7 & 4 \\
$\begin{array}{l}\text { Croton megalobotrys - Combretum } \\
\text { microphyllum Closed Woodland }\end{array}$ & 5103 & 18 & 2 \\
$\begin{array}{l}\text { Faidherbia albida-Panicum maximum } \\
\text { Closed Woodland }\end{array}$ & 2287 & 8 & 0 \\
$\begin{array}{l}\text { Hexalobus monopetalus - Bulbostylis } \\
\text { hispidula Open Shrubland }\end{array}$ & 1640 & 6 & 3 \\
$\begin{array}{l}\text { Vachellia (Acacia) stuhlmannii Open } \\
\text { Shrubland }\end{array}$ & 6698 & 24 & 1 \\
\hline \begin{tabular}{l} 
Total \\
\hline
\end{tabular} & $\mathbf{2 8 4 5 9}$ & $\mathbf{1 0 0}$ & $\mathbf{2 0}$ \\
\hline
\end{tabular}

Source: Computed from vegetation maps provided by Scientific Services data repository

\section{Data analysis}

Statistical analyses were performed using $\mathrm{R}$ ( $\mathrm{R}$ Core Team 2012). We used lme4 (Bates et al. 2015) to perform linear mixed effects analyses of the relationship of various indicators of browsing impact, that is, broken branches, twigs browsed and stem damage (both pollarded and pushed over) with vegetation characteristics. Only vegetation types with at least three sites sampled were retained in the regression analyses, that is, Commiphora species - Sesamothamnus lugardii Closed Shrubland, Colophospermum mopane-Brachiaria deflexa Closed Woodland, Hexalobus monopetalus - Bulbostylis hispidula Open Shrubland and Senegalia (Acacia) senegal - Barleria sinensis Closed Shrubland. The entire site (all four transects) was amalgamated into one sample to avoid pseudoreplication during statistical analyses. As fixed effects, vegetation type, height and whether plants were single-stemmed or multistemmed were entered into the model and site was included as a random effect. The most parsimonious model was selected by first fitting the maximum model, removing nonsignificant interaction terms and comparing models using ANOVA (analysis of variance) and Akaike Information Criterion (Crawley 2012). As none of the fixed effects contributed significantly to explaining variability in bark stripping and trees pushed over, species was included as a random effect for these two categories.

We determined which of the most common species occurred on both ridges and flats (see Figure 1-A1 for examples of these landscapes) and tested for differences in the utilisation of two branch size classes $(0 \mathrm{~mm}-10 \mathrm{~mm}$ and $20 \mathrm{~mm}-50 \mathrm{~mm})$ for these species at the two localities using a Wilcoxon Signed-Rank Test. We assumed that smaller browsers were responsible for breaking $0 \mathrm{~mm}-10 \mathrm{~mm}$ branches, and elephants for breaking $20 \mathrm{~mm}-50 \mathrm{~mm}$ branches.

\section{Results}

We encountered a total of 1740 plants of 65 different species. Six species accounted for $52 \%$ of all the plants encountered (Table 1-A1). We excluded all species for which we sampled less than 10 individuals from the analyses, leaving a total of 34 species and 1609 individuals (listed in Table 2-A1). All species showed obvious signs of herbivore impact except for Mundulea sericea (cork-bush), Catophractes alexandri (gabbabos) and Rhigozum zambesiacum (mopane rhigozum). Evidence of twig browsing was found in $83 \%$ of plants, while $71 \%$ had broken branches, $4 \%$ had stripped branches, $6 \%$ had stripped bark, $3 \%$ had main stems broken or pollarded and 9\% were toppled.

Only 11 species had less than $60 \%$ of trees with broken branches (Figure 2a). Many species, and Commiphora species and Sterculia rogersii (star-chestnut) in particular, experienced high rates of toppling (Figure 2b). Elephants and other browsers appeared to target very specific tree species for debarking, with only three species having more than $10 \%$ of bark damage (data not shown, Lannea schweinfurthii [false marula] 0.20, Sesamothamnus lugardii [sesame-bush] 0.75 and 


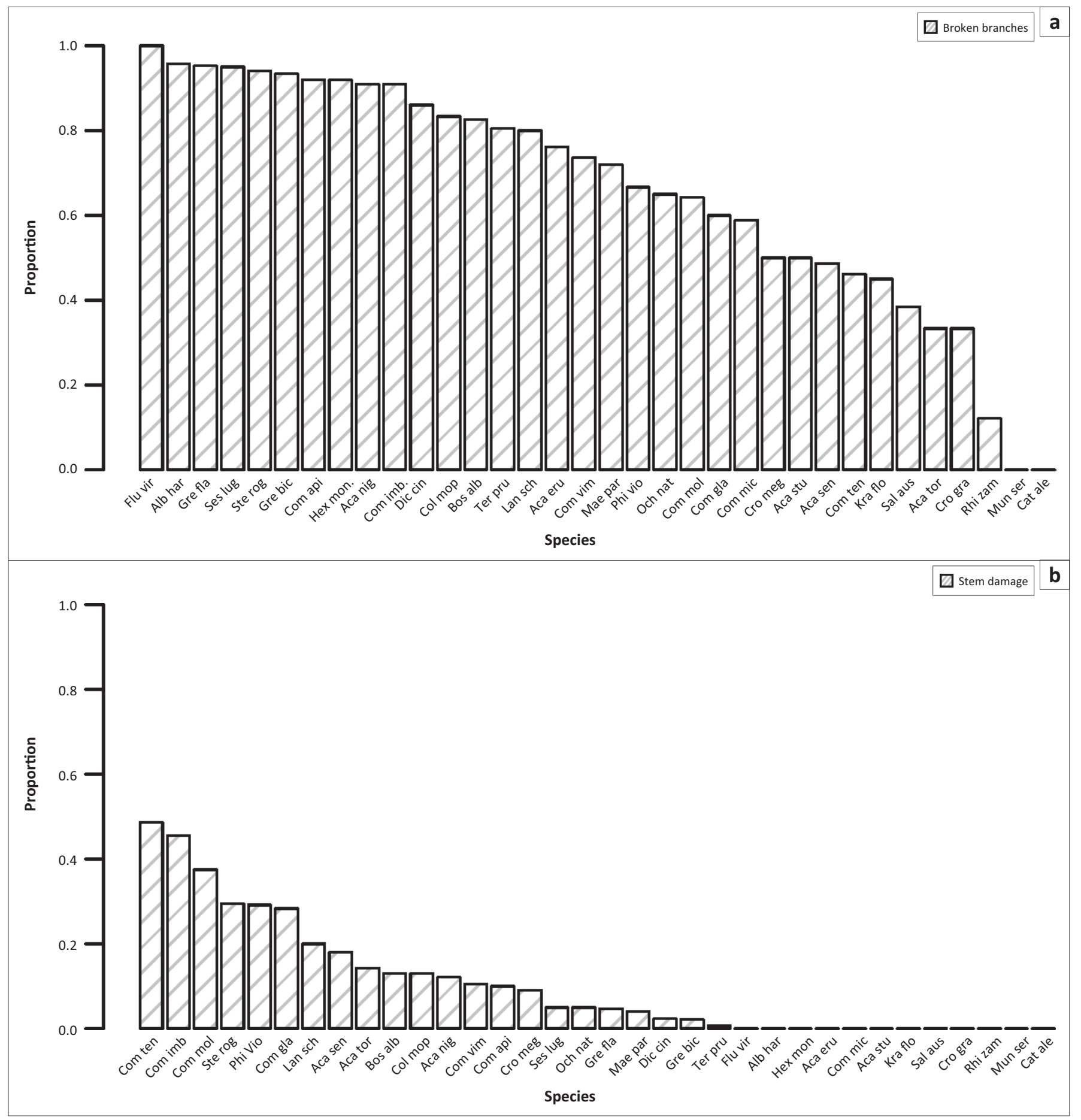

FIGURE 2: The proportion of each species with (a) broken branches and (b) stem damage.

Sterculia rogersii 0.29). Although not confirmed, it appeared that the bark was removed by animals other than elephants for some of these species (e.g. eland or kudu for Sesamothamnus lugardii).

Twig browsing, or browsing impact attributable to animals other than elephants, was high for many species, with only nine species having less than $70 \%$ of individuals impacted (Figure 3a). Giraffe tended to target specific species (e.g. Senegalia [Acacia] nigrescens [knobthorn], Combretum apiculatum [red bushwillow], Dichrostachys cinerea [sickle bush] and Lannea schweinfurthii) (Figure 3b).
All browsing indicators were uniformly high across vegetation types. More broken branches were encountered in the middle height class $(2.5 \mathrm{~m}-5 \mathrm{~m})$ than in other height classes and in multi-stemmed plants than in single-stemmed plants (see Table 3-A1 for results from glmer, Figure 4a and b). Although stemmedness overall did not affect twig browsing, in the $2.5 \mathrm{~m}-5 \mathrm{~m}$ height class, higher proportions of multistemmed than single-stemmed plants were browsed (Figure 5a and $b$ ). The probability of bark stripping and trees being pushed over could not be predicted by vegetation type, stemmedness or height, but some transects were more impacted than others (data not shown). Including species as a 


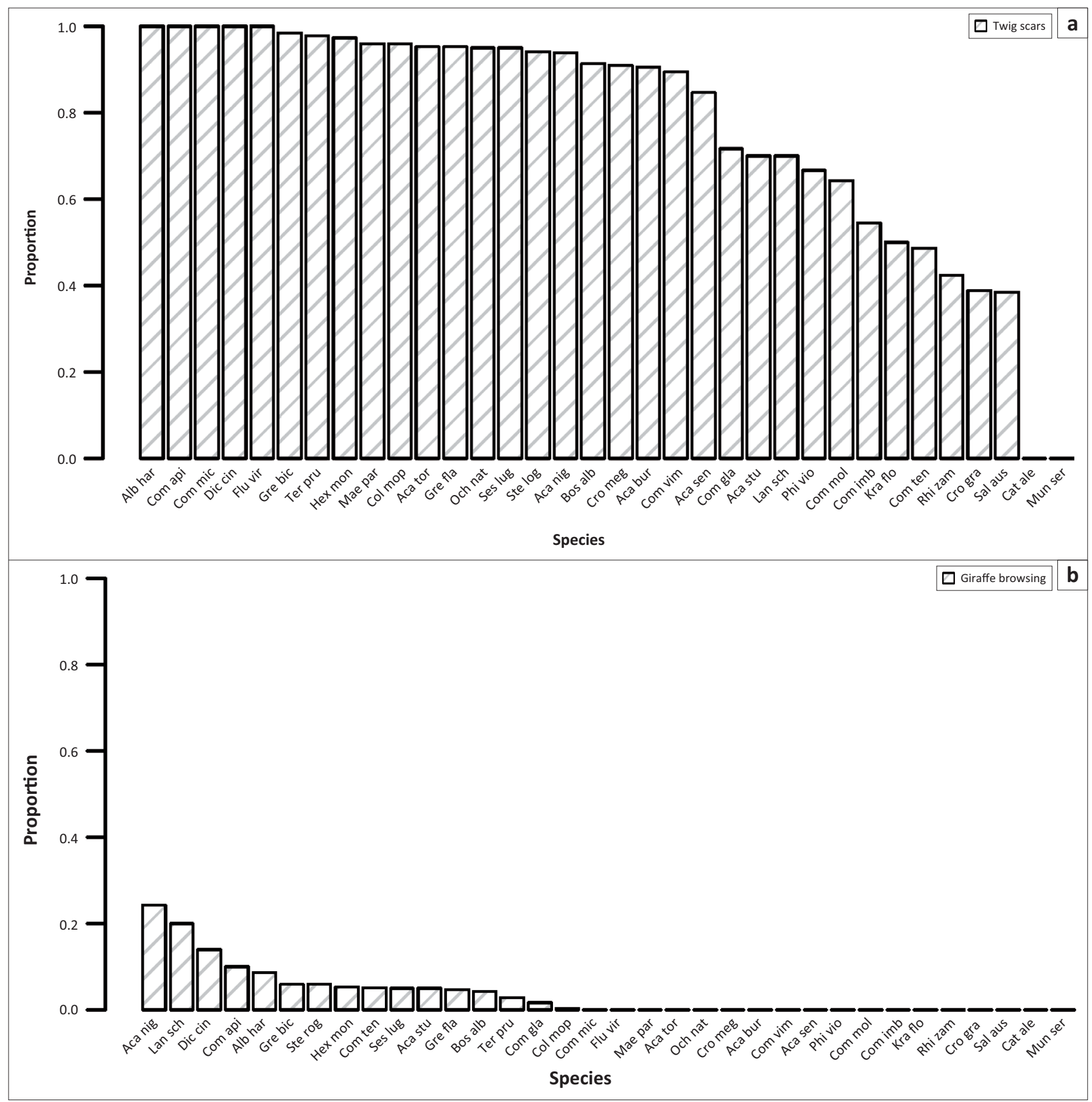

FIGURE 3: The proportion of each species with (a) twig scars (branches $<10 \mathrm{~mm}$ diameter) and (b) stripped branches (giraffe browsing).

random effect significantly improved the fit of the model (Table 3-A1).

Twelve species commonly occurred in ridges and flats. Utilisation of $0 \mathrm{~mm}-10 \mathrm{~mm}$ branches was significantly higher ( $p<0.0001$, Figure 6a) on the ridges for these 12 species than it was in flat areas, but there was no difference between areas in the $20 \mathrm{~mm}-50 \mathrm{~mm}$ branch size class ( $p=0.17$, Figure $6 \mathrm{~b}$ ).

\section{Discussion}

This study assessed whether the high elephant impacts observed within riparian forests in Mapungubwe $\left(\mathrm{O}^{\prime}\right.$ Connor
2010; SAEON, unpublished data; OTS, unpublished data) also occur in the main vegetation types there. Elephants and other herbivores have significant impacts on structure in savannas elsewhere (Asner et al. 2009; Eckhardt, Wilgen \& Biggs 2000). Apart from the Vachellia (Acacia) stuhlmannii Open Shrubland vegetation type which browsers seem to avoid, we found impacts by elephants and other browsers to be uniformly high across all the other remaining vegetation types surveyed. Browser impacts measured here are high (e.g. 71\% of plants had broken branches and $83 \%$ of plants had browsed twigs) compared with those in other conservation areas. Peel et al. (1998) showed that in the Sabi Sand Reserve, only $12 \%$ of surveyed trees had elephant impact at elephant densities of 


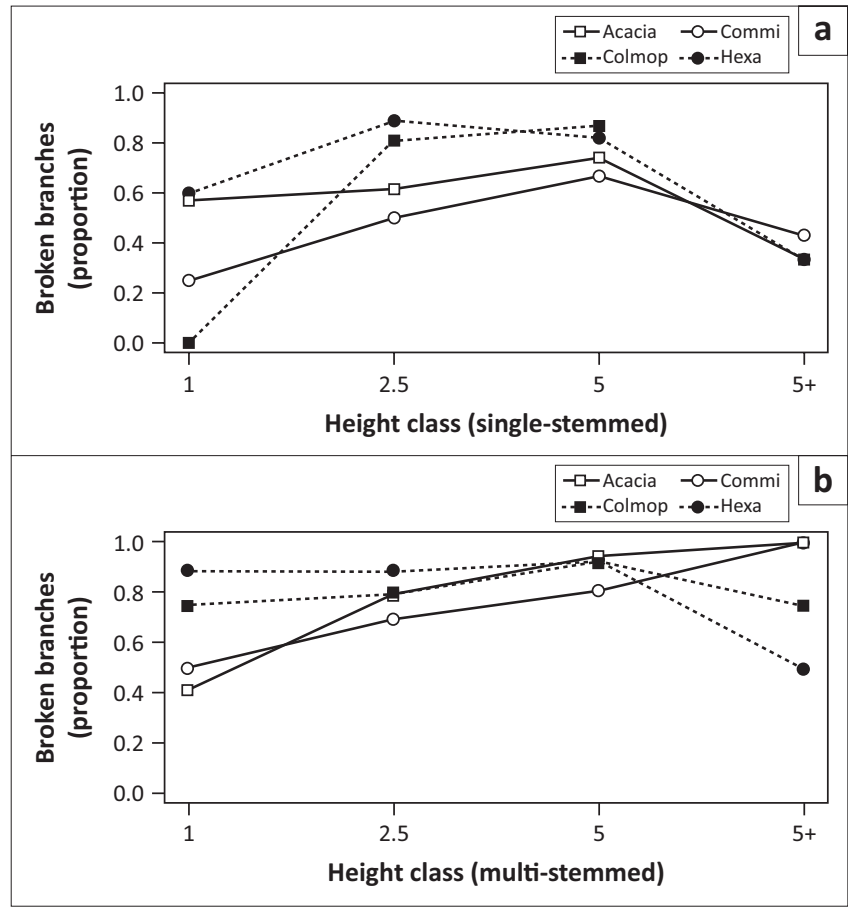

Colmop, Colophospermum mopane - Brachiaria deflexa Closed Woodland; Commi, Commiphora species - Sesamothamnus lugardii Closed Shrubland; Hexa, Hexalobus monopetalus - Bulbostylis hispidula Open Shrubland and Acacia, Senegalia (Acacia) senegal Barleria sinensis Closed Shrubland.

FIGURE 4: Proportion of plants with broken branches among vegetation types for (a) single-stemmed plants and (b) multi-stemmed plants.

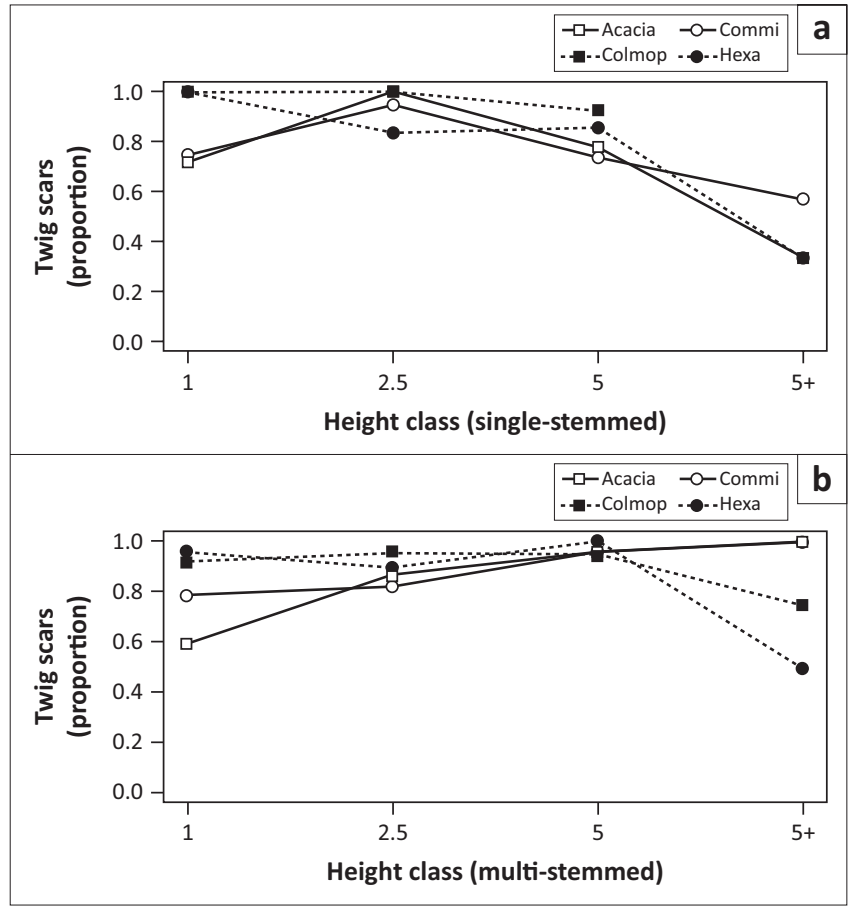

Colmop, Colophospermum mopane - Brachiaria deflexa Closed Woodland; Commi, Commiphora species - Sesamothamnus lugardii Closed Shrubland; Hexa, Hexalobus monopetalus - Bulbostylis hispidula Open Shrubland and Acacia, Senegalia (Acacia) senegalBarleria sinensis Closed Shrubland.

FIGURE 5: Proportion of plants with twigs browsed among vegetation types for (a) single-stemmed plants and (b) multi-stemmed plants.

0.7 elephant per $\mathrm{km}^{-2}$, while in the southern section of the Kruger National Park (KNP), 60\% of trees sampled exhibited elephant utilisation at densities of 1.1 elephant per $\mathrm{km}^{-2}$ (Shannon et al. 2008). In the Venetia Limpopo Nature Reserve

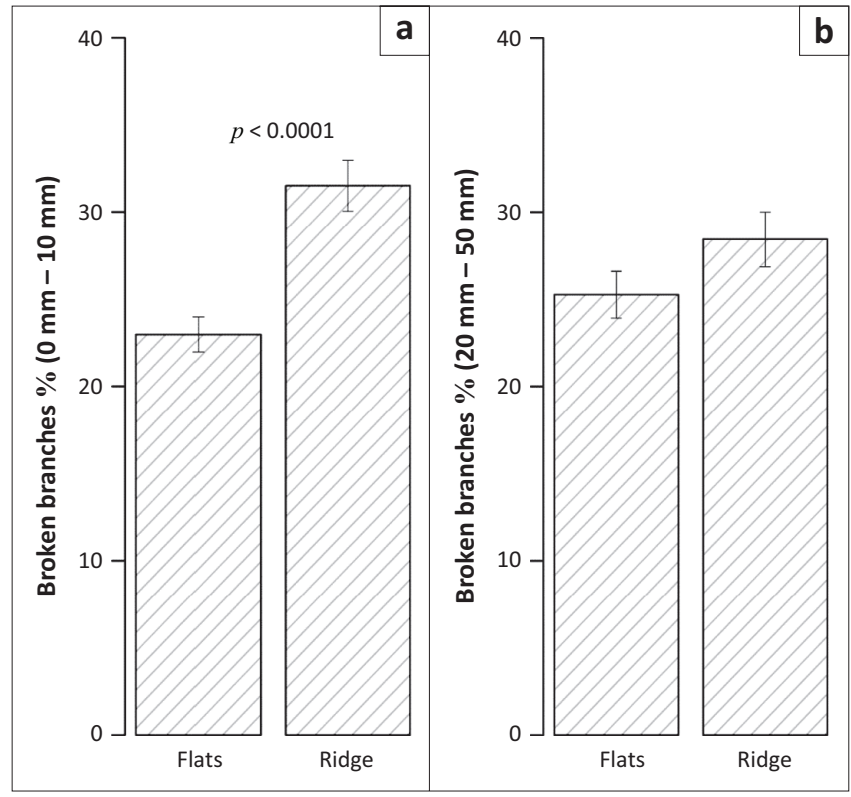

FIGURE 6: Mean proportion of broken branches on ridges versus flats for 12 species that were commonly found in both areas: (a) in $0 \mathrm{~mm}-10 \mathrm{~mm}$ branch size class (Wilcoxon Signed-Rank Test; $W=92622, p<0.0001$ ) and (b) in in $20 \mathrm{~mm}-50 \mathrm{~mm}$ branch size class (Wilcoxon Signed-Rank Test; $W=41$ 824, $p=0.17$ ).

adjacent to Mapungubwe, O'Connor and Page (2014) found that both mopane-dominated woodlands and Commiphoradominated woodlands were heavily utilised by elephants.

Elephants have been shown to increase their nutrient intake by selecting browse from nutrient-rich patches (Pretorius et al. 2011). We therefore expected elephants and other browsers in Mapungubwe to have a lower impact on the mopane-dominated vegetation type associated with nutrientpoor Kalahari sands (Wigley, unpublished data). Surprisingly, this was not found to be the case as our results did not show this, with high levels of utilisation being evident across all vegetation and soil types.

Current, high utilisation levels of certain species by elephants in Mapungubwe are unlikely to be sustainable. Elephants have toppled a third of the combined populations of Commiphora glandulosa (tall firethorn corkwood), Commiphora mollis (velvetleaved corkwood) and Commiphora tenuipetiolata (satin-bark corkwood) and these, once toppled, are likely to die as these species' inability to resprout makes them vulnerable, with few Commiphora seedlings or saplings being found in our surveys. Elephants have been shown to be responsible for reducing Commiphora species in other studies. For example, a $67 \%$ reduction of a population of Commiphora ugogensis (river corkwood) was recorded over a 6-year period in Ruaha National Park, Kenya (Barnes 1985), while elephants also caused huge decreases in the cover of Commiphora woodlands in Tsavo National Park, Tanzania (Leuthold 1996). Many of the same Commiphora species found in Mapungubwe have become locally extinct in the neighbouring, and now continuous, Tuli Block because of the impact of elephants ( $\mathrm{O}^{\prime}$ Connor et al. 2007).

O'Connor and Page (2014) showed huge decreases in certain tree species in the neighbouring Venetia Limpopo Nature 
Reserve, including Vachellia (Acacia) nilotica (scented-pod thorn), Vachellia (Acacia) tortilis (umbrella thorn), Albizia anthelmintica (worm-cure albizia), Cadaba termitaria (greyleaved wormbush), most Commiphora species, Ximenia americana (sourplum) and Ziziphus mucronata (buffalo-thorn). Vachellia (Acacia) xanthophloea woodlands recovered after elephants were fenced out in the semi-arid Amboseli National Park in Kenya (Western \& Maitumo 2004). Similarly, Wigley et al. (2014) showed that population demographics of many tree species remained healthy when protected from elephants (but not fire) within enclosures in the KNP, South Africa.

We tested whether steep slopes and rocky outcrops were acting as refuges and recruitment hotspots for plants. Despite the numerous potential areas in Mapungubwe that may harbour rare vegetation and plants, our results suggest that the vegetation growing on ridges compared with flat areas is equally or more heavily utilised by browsers. Although we attempted to sample communities on ridges that were either difficult or impossible for elephants to access, we failed to find significant numbers of recruits or plants with low levels of herbivore impact in these areas. This may be because vegetation on the rocky ridges has more access to water than does vegetation on the flat areas during dry periods and thus appeals to many browsers. Vegetation on bedrock outcrops elsewhere has been shown to access rainwater stored in fissures and crevices and spring water (see Nie et al. 2011 and sources therein). Wall, Douglas-Hamilton and Vollrath (2006) showed that elephant densities were much lower on minor hills in northern Kenya and that they avoided steep hills altogether. Another Kenyan study showed that elephants avoided steep hills and high elevations in summer but preferred high elevations in winter when evergreen forests provide more food than do the deciduous shrub-dominated lowlands (Ngene et al. 2009). Broken branches in the larger $20 \mathrm{~mm}-50 \mathrm{~mm}$ branch class did not differ between vegetation in flat compared with ridged areas, which may indicate that elephant impact is less important than that of the smaller herbivores on ridges.

Although megaherbivores, such as elephants, have been shown to have a strong influence on all woody size classes (e.g. Asner et al. 2015; Ben-Shahar 1993; Bond \& Loffell 2001), meso-browsers may influence recruitment of small-size classes and seedlings (e.g. Augustine \& Mcnaughton 2004; Barnes 2001; Prins \& Van der Jeugd 1993). Impalas have been shown to suppress Vachellia (Acacia) tortilis recruitment in Tanzania, with establishment occurring only during a reduction in browsing pressure, as it did in the rinderpest pandemic at the end of the 1880s (Prins \& Van der Jeugd 1993). Once large trees and woodland are reduced by elephants, it seems that impalas often manage to suppress recruitment, especially of palatable species, thereby transforming it into depauperate shrubland (Moe et al. 2009; O'Kane et al. 2012). At Mapungubwe, herbivores other than elephants seem to contribute significantly to the high utilisation of vegetation on ridges.

\section{Conclusion}

Whether the high rates of utilisation and associated changes in vegetation occurring at present are an artefact of higher historical recruitment rates when elephants were absent from this area or the result of a wetter climate remains an enigma. Elephants are also funnelled into Mapungubwe from Botswana and Zimbabwe because of increased hunting (including illegal hunting) of elephants and ongoing developmental activities in those countries. As suggested by O'Connor and Page (2014) and O'Connor (2010), elephants cannot co-exist with certain plant species. Our findings suggest that without the creation of botanical reserves that exclude elephant and other browsers, structural diversity, if not species diversity, is likely to be lost in Mapungubwe in the near future. Whether this is seen as a problem or simply as a return to a previous alternative state will depend on current and future management paradigms.

\section{Acknowledgements}

The authors thank SANParks management and Scientific Services staff for their assistance, especially Steven Khoza for his valuable help in the field. Comments and suggestions from Yolanda Pretorius and two anonymous reviewers helped improve this manuscript. Funding was made available by Nelson Mandela Metropolitan University, Science Faculty, through the Research Development Fund.

\section{Competing interests}

The authors declare that they have no financial or personal relationships which may have inappropriately influenced them in writing this article.

\section{Authors' contributions}

C.C. and B.J.W. developed the project and conducted the fieldwork, C.C. performed statistical analyses and prepared the manuscript and B.J.W. made all graphics and assisted in manuscript preparation.

\section{References}

Asner, G.P., Levick, S.R., Kennedy-Bowdoin, T., Knapp, D.E., Emerson, R., Jacobson, J. et al., 2009, 'Large-scale impacts of herbivores on the structural diversity of African savannas', Proceedings of the National Academy of Sciences 106, 4947-4952.

Asner, G.P., Vaughn, N., Smit, I.P. \& Levick, S., 2015, 'Ecosystem-scale effects of megafauna in African savannas', Ecography 38, http://dx.doi.org/10.1111/ ecog.01640

Augustine, D.J. \& Mcnaughton, S.J., 2004, 'Regulation of shrub dynamics by native browsing ungulates on East African rangeland', Journal of Applied Ecology 41, 45-58. http://dx.doi.org/10.1111/j.1365-2664.2004.00864.x

Barnes, M.E., 2001, 'Effects of large herbivores and fire on the regeneration of Acacia erioloba woodlands in Chobe National Park, Botswana', African Journal of Ecology 39, 340-350. http://dx.doi.org/10.1046/j.1365-2028.2001.00325.x

Barnes, R.F.W., 1985, 'Woodland changes in Ruaha National park (Tanzania) between 1976 and 1982', African Journal of Ecology 23, 215-221. http://dx.doi. org/10.1111/j.1365-2028.1985.tb00952.x

Bates, D.M., Maechler, M., Bolker, B. \& Walker, S., 2015, 'Fitting linear mixed effects models using Ime4', Journal of Statistical Software 67, 1-48.. http://dx.doi. org/10.18637//jss.v067.i01

Ben-Shahar, R., 1993, 'Patterns of elephant damage to vegetation in northern Botswana', Biological Conservation 65, 249-256. http://dx.doi.org/10.1016/00063207(93)90057-8 
Bond, W.J., 2005, 'Large parts of the world are brown or black: A different view on the "Green World" hypothesis', Journal of Vegetation Science 16, 261-266. http:// dx.doi.org/10.1658/1100-9233(2005)016[0261:Ipotwa]2.0.co;2

Bond, W.J. \& Loffell, D., 2001, 'Introduction of giraffe changes acacia distribution in a South African savanna', African Journal of Ecology 39, 286-294. http://dx.doi. org/10.1046/j.1365-2028.2001.00319.x

Campos-Arceiz, A. \& Blake, S., 2011, 'Megagardeners of the forest-the role of elephants in seed dispersal', Acta Oecologica 37, 542-553. http://dx.doi. org/10.1016/j.actao.2011.01.014

Caughley, G., 1976, 'The elephant problem-an alternative hypothesis', African Journal of Ecology 14, 265-283. http://dx.doi.org/10.1111/j.1365-2028.1976.tb00242.x

Crawley, M.J., 2012, The R book, John Wiley \& Sons Ltd, The Atrium, Southern Gate, Chichester, West Sussex, England.

De Beer, G.C.O., 2007, The impact of elephants (Loxodonta africana) on the Limpopo riparian forests and associated plant communities in the semi-arid region of the Limpopo Province (July 2006). Unpublished report, 78 pp. Biodiversity Management, Limpopo Provincial Government, Polokwane, South Africa.

De Beer, Y., Kilian, W., Versfeld, W. \& Van Aarde, R.J., 2006, 'Elephants and low rainfal alter woody vegetation in Etosha National Park, Namibia', Journal of Arid Environments 64, 412-421.

Eckhardt, H.C., Wilgen, B.W. \& Biggs, H.C., 2000, 'Trends in woody vegetation cover in the Kruger National Park, South Africa, between 1940 and 1998', African Journa of Ecology 38, 108-115. http://dx.doi.org/10.1046/j.1365-2028.2000.00217.x

Gandiwa, E., Magwati, T., Zisadza, P., Chinuwo, T. \& Tafangenyasha, C., 2011, 'The impact of African elephants on Acacia tortilis woodland in northern Gonarezhou National Park, Zimbabwe', Journal of Arid Environments 75, 809-814. http://dx. doi.org/10.1016/j.jaridenv.2011.04.017

Guldemond, R. \& Van Aarde, R., 2008, 'A meta-analysis of the impact of African elephants on savanna vegetation', The Journal of Wildlife Management 72, 892-899. http://dx.doi.org/10.2193/2007-072

Holdo, R.M., 2007, 'Elephants, fire, and frost can determine community structure and composition in Kalahari woodlands', Ecological Applications 17, 558-568. http:// dx.doi.org/10.1890/05-1990

Holdo, R.M., Holt, R.D. \& Fryxell, J.M., 2009, 'Grazers, browsers, and fire influence the extent and spatial pattern of tree cover in the Serengeti', Ecological Applications 19, 95-109. http://dx.doi.org/10.1890/07-1954.1

Huffman, T.N., 2000, 'Mapungubwe and the origins of the Zimbabwe culture', South African Archaeology Society Goodwin Series 8, 14-29.

Kyalangalilwa, B., Boatwright, J.S., Daru, B.H., Maurin, O. \& Bank, M., 2013, 'Phylogenetic position and revised classification of Acacia sl (Fabaceae: Mimosoideae) in Africa, including new combinations in Vachellia and Senegalia' Botanical Journal of the Linnean Society 172, 500-523. http://dx.doi.org/10.1111/ boj.12047

Kerley, G.I.H. \& Landman, M., 2006, 'The impacts of elephants on biodiversity in the Eastern Cape subtropical thickets', South African Journal of Science 102, 395-402.

Kerley, G.I.H., Landman, M., Kruger, L. \& Owen-Smith, N., 2008, 'Chapter 3: Effects of elephants on ecosystems and biodiversity', in R.J. Scholes \& K.G. Mennell (eds.), Elephant management: A scientific assessment for South Africa, n.p., Wits University Press, Johannesburg.

Landman, M., Gaylard, A., Mendela, T. \& Kerley, G.I., 2014, 'Impact of elephant on two woody trees, Boscia oleoides and Pappea capensis, in an arid thicket-Nama Karoo mosaic, Greater Addo Elephant National Park: Short communication', Koedoe 56 1-3. http://dx.doi.org/10.4102/koedoe.v56i1.1231

Leuthold, W., 1996, 'Recovery of woody vegetation in Tsavo National Park, Kenya, 1970-94', African Journal of Ecology 34, 101-112. http://dx.doi.org/10.1111/j. 1365-2028.1996.tb00605.x

Midgley, J.J., Lawes, M.J. \& Chamaillé-Jammes, S., 2010, 'TURNER REVIEW No. 19 savanna woody plant dynamics: The role of fire and herbivory, separately and synergistically', Australian Journal of Botany 58, 1-11. http://dx.doi.org/10.1071/ BT09034

Moe, S.R., Rutina, L.P., Hytteborn, H. \& Du Toit, J.T., 2009, 'What controls woodland regeneration after elephants have killed the big trees?', Journal of Applied Ecology 46, 223-230. http://dx.doi.org/10.1111/j.1365-2664.2008.01595.x

Moncrieff, G.R., Kruger, L.M. \& Midgley, J.J., 2008, 'Stem mortality of Acacia nigrescens induced by the synergistic effects of elephants and fire in Kruger National Park South Africa', Journal of Tropical Ecology 24, 655-662. http://dx.doi.org/10.1017/ South Africa', Journal

Mucina, L. \& Rutherford, M.C., 2006, The vegetation of South Africa, Lesotho and Swaziland, South African National Biodiversity Institute, Pretoria.
Ngene, S.M., Skidmore, A.K., Van Gils, H., Douglas-Hamilton, I. \& Omondi, P., 2009, 'Elephant distribution around a volcanic shield dominated by a mosaic of forest and savanna (Marsabit, Kenya)', African Journal of Ecology 47, 234-245. http:// and savanna (Marsabit, Kenya)', African Journal
dx.doi.org/10.1111/j.1365-2028.2008.01018.x

Nie, Y.P., Chen, H.S., Wang, K.L., Tan, W., Deng, P.Y. \& Yang, J., 2011, 'Seasonal water use patterns of woody species growing on the continuous dolostone outcrops and nearby thin soils in subtropical China', Plant and Soil 341, 399-412. http://dx.doi. org/10.1007/s11104-010-0653-2

O'Connor, T.G., 2010, 'Transformation of riparian forest to woodland in Mapungubwe National Park, South Africa, between 1990 and 2007', Austral Ecology 35, 778-786. http://dx.doi.org/10.1111/j.1442-9993.2009.02084.x

O'Connor, T.G., Goodman, P.S. \& Clegg, B., 2007, 'A functional approach hypothesis of the threat of local extirpation of woody plant species by elephant in Africa', Biological Conservation 136, 329-345. http://dx.doi.org/10.1016/j.biocon.2006.12.014

O'Connor, T.G. \& Kiker, G.A., 2004, 'Collapse of the Mapungubwe Society: Vulnerability of pastoralism to increasing aridity', Climatic Change 66, 49-66. http://dx.doi. org/10.1023/B:CLIM.0000043192.19088.9d

O'Connor, T.G. \& Page, B.R., 2014, 'Simplification of the composition, diversity and structure of woody vegetation in a semi-arid African savanna reserve following the re-introduction of elephants', Biological Conservation 180, 122-133. http:// dx.doi.org/10.1016/j.biocon.2014.09.036

O'Kane, C.A., Duffy, K.J., Page, B.R. \& Macdonald, D.W., 2012, 'Heavy impact on seedlings by the impala suggests a central role in woodland dynamics', Journal of Tropical Ecology 28, 291-297. http://dx.doi.org/10.1017/S026646741200017X

Owen-Smith, N., 1989, 'Megafaunal extinctions: The conservation message from 11,000 years BP', Conservation Biology 3, 405-412. http://dx.doi.org/10.1111/j. 1523-1739.1989.tb00246.x

Peel, M.J.S., Peel, J., McNamara, T. \& Jacobs, A., 1998, 'Ecological monitoring: Sab Sand Wildtuin', Range and Forage Institute Report no. 5. Unpublished.

Pretorius, Y., De Boer, F.W., Van der Waal, C., De Knegt, H.J., Grant, R.C., Knox, N.M. et al., 2011, 'Soil nutrient status determines how elephant utilize trees and shape environments', Journal of Animal Ecology 80, 875-883. http://dx.doi.org/10.1111/ j.1365-2656.2011.01819.x

Prins, H.H.T. \& Van Der Jeugd, H.P., 1993, 'Herbivore population crashes and woodland structure in East Africa', Journal of Ecology 81, 305-314. http://dx.doi. org/10.2307/2261500

R Core Team, 2012, 'R: A language and environment for statistical computing', R Foundation for Statistical Computing, Vienna, Austria, ISBN 3-900051-07-0, viewed from http://www.R-project.org

Selier, J., 2007, Report on the total elephant aerial count June 2007. Unpublished report, Faculty of Natural and Agricultural Science, University of Pretoria, Pretoria, $16 \mathrm{p}$

Shannon, G., Druce, D.J., Page, B.R., Eckhardt, H.C., Grant, R. \& Slotow, R., 2008, 'The utilisation of large savanna trees by elephant in southern Kruger National Park', Journal of Tropical Ecology 24, 281-289. http://dx.doi.org/10.1017/S02664674 08004951

Shannon, G., Thaker, M., Vanak, A.T., Page, B.R., Grant, R. \& Slotow, R., 2011, 'Relative impacts of elephant and fire on large trees in a savanna ecosystem', Ecosystems 14, 1372-1381. http://dx.doi.org/10.1007/s10021-011-9485-z

South African Defence Force, 1986a, Report on the vegetation of the map areas 2229AA, Pontdrif and 2229AC, Evangelina, Unpublished report, South African Defence Force, Pretoria.

South African Defence Force, 1986b, Report on the vegetation of the map areas 2229AB, Mapungubwe and 2229AD, Coila, Unpublished report, South African Defence Force, Pretoria.

Valeix, M., Fritz, H., Sabatier, R., Murindagomo, F., Cumming, D. \& Duncan, P., 2011 'Elephant-induced structural changes in the vegetation and habitat selection by large herbivores in an African savanna', Biological Conservation 144, 902-912. large herbivores in an African savanna, Biological
http://dx.doi.org/10.1016/j.biocon.2010.10.029

Wall, J., Douglas-Hamilton, I. \& Vollrath, F., 2006, 'Elephants avoid costly mountaineering', Current Biology 16, R527-R529. http://dx.doi.org/10.1016/j. cub.2006.06.049

Western, D. \& Maitumo D., 2004, 'Woodland loss and restoration in a savanna park: A 20-year experiment', African Journal of Ecology 42, 111-121. http://dx.doi. org/10.1111/j.1365-2028.2004.00506.x

Wigley, B.J., Fritz, H., Coetsee, C. \& Bond, W.J., 2014, 'Herbivores shape woody plant communities in the Kruger National Park: Lessons from three long-term exclosures', Koedoe 56, 1-12. http://dx.doi.org/10.4102/koedoe.v56i1.1165 


\section{Appendix 1}

TABLE 1-A1: Patterns of utilisation for the six most common species in Mapungubwe National Park.

\begin{tabular}{lcccc}
\hline Species & Density (trees ha ${ }^{-1}$ ) & Broken branches & Twigs browsed & Boppled \\
\hline Combretum apiculatum & 46 & 0.92 & 1.00 & 0.05 \\
Colophospermum mopane & 77 & 0.83 & 0.95 & 0.00 \\
Commiphora mollis & 18 & 0.64 & 0.64 & 0.03 \\
Commiphora glandulosa & 19 & 0.60 & 0.71 & 0.02 \\
Grewia bicolor & 42 & 0.93 & 0.98 & 0.09 \\
Terminalia prunoides & 43 & 0.81 & 0.98 & 0.00 \\
\hline
\end{tabular}

Patterns of utilisation for the six most common species encountered in transects. Twig browsing (browsing on twigs less than 5 mm), bark removed and toppling (included pushed over alive or dead as well as uprooted) are recorded as the proportions with utilisation to the total number.

TABLE 2-A1: Names and abbreviations used for the 34 species that had a sample size of 10 or higher.

\begin{tabular}{ll}
\hline Species & Abbreviation \\
\hline Albizia harveyi & Alb har \\
Boscia albitrunca & Bos alb \\
Catophractes alexandri & Cat ale \\
Colophospermum mopane & Col mop \\
Combretum apiculatum & Com api \\
Combretum imberbe & Com imb \\
Combretum microphyllum & Com mic \\
Commiphora glandulosa & Com gla \\
Commiphora mollis & Com mol \\
Commiphora tenuipetiolata & Com ten \\
Commiphora viminea & Com vim \\
Croton gratissimus & Cro gra \\
Croton megalobotrys & Cro meg \\
Dichrostachys cinerea & Dic cin \\
Flueggea virosa & Flu vir \\
Grewia bicolor & Gre bic \\
Grewia flavescens & Gre fla \\
Hexalobus monopetalus & Hex mon \\
Kraussia floribunda & Kra flo \\
Lannea schweinfurthii & Lan sch \\
Maerua parvifolia & Mae par \\
Mundulea sericea & Mun ser \\
Ochna natalitia & Och nat \\
\hline Philenoptera violacea & Phi vio \\
\hline Rhigozum zambesiacum & Rhi zam \\
\hline Salvadora australis & Sal aus \\
\hline Senegalia & Aca nig \\
\hline
\end{tabular}


TABLE 3-A1: Best fit model results of the relationships between proportions of trees with specific browser damage and the tested predictors using Generalised Linear Models (with binomial errors).

\begin{tabular}{|c|c|c|c|c|}
\hline Trees & Estimate & Std. Error & $Z$ value & AIC \\
\hline \multicolumn{5}{|l|}{ Broken branches } \\
\hline Intercept & 0.92 & 0.33 & $0.005^{* *}$ & - \\
\hline Single stem & -0.98 & 0.16 & $-5.93 * * *$ & - \\
\hline Height 2 & 0.86 & 0.24 & $3.63 * * *$ & - \\
\hline Height 3 & 1.62 & 0.25 & $6.54 * * *$ & - \\
\hline Height 4 & 0.29 & 0.42 & 0.70 & - \\
\hline \multicolumn{5}{|l|}{ Twigs browsed } \\
\hline Intercept & 2.25 & 0.43 & $5.27 * * *$ & - \\
\hline Single stem & -0.27 & 0.56 & -0.49 & - \\
\hline Height 2 & 0.29 & 0.33 & 0.38 & - \\
\hline Height 3 & 1.75 & 0.41 & $4.20 * * *$ & - \\
\hline Single stem: Height 2 & 1.11 & 0.74 & 1.50 & - \\
\hline Single stem: Height 3 & -2.00 & 0.65 & $-3.06 * *$ & - \\
\hline Single stem: Height 4 & -1.64 & 1.07 & -1.53 & - \\
\hline \multicolumn{5}{|l|}{ Bark stripping } \\
\hline Intercept (only site as random effect) & -4.59 & 0.53 & $-8.65 * * *$ & 278 \\
\hline Intercept (site and species as random effects) & - & - & - & 189 \\
\hline Pushed over (alive) & -4.95 & 0.58 & $-8.48 * * *$ & - \\
\hline Intercept (only site as random effect) & - & - & - & 185 \\
\hline Intercept (site and species as random effects) & -6.36 & 1.05 & $-6.07 * * *$ & 177 \\
\hline
\end{tabular}

Estimates are presented for parameters retained in the best (minimum adequate) model.

Height class $1=0 \mathrm{~m}-1 \mathrm{~m}$, class $2=1 \mathrm{~m}-2.5 \mathrm{~m}$, class $3=2.5 \mathrm{~m}-5 \mathrm{~m}$ and class $4=>5 \mathrm{~m}$, Stem classes $=$ Single or multi stemmed

*, Significant at $P<0.05 ; * *$, Significant at $P<0.01 ; * * *$, Significant at $P<0.001$
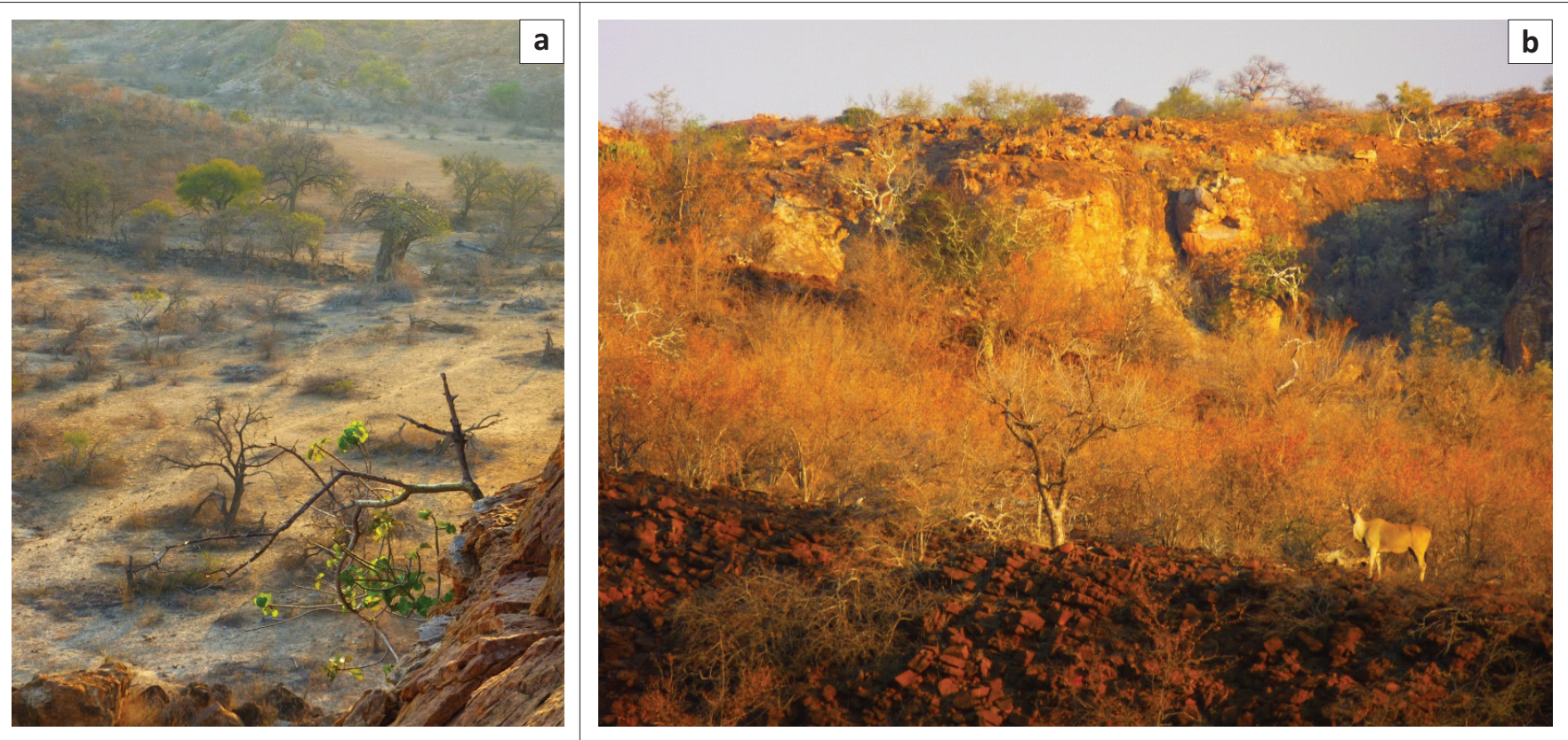

Source: Corli Coetsee

FIGURE 1-A1: Examples of typical (a) vegetation found on flats as opposed to (b) ridges in Mapungubwe National Park. 